\title{
THE LONG SHORTLIST: WOMEN CONSIDERED FOR THE SUPREME COURT
}

\author{
Michael Conklin* \\ "Oft a bridesmaid-never a bride" \\ -Susie Sharp, on being considered for the Supreme Court
}

\section{INTRODUCTION}

This is a review of the book Shortlisted: Women in the Shadows of the Supreme Court. ${ }^{1}$ While much has been written about the four women who were ultimately selected to serve as Supreme Court justices, this book provides insight into the many women who were shortlisted but ultimately not appointed to the Court. This surprisingly dates back to 1924, when evidence suggests that President Calvin Coolidge shortlisted Florence Allen. ${ }^{2}$ While the book is highly recommended, this review mainly focuses on areas of critique, including misleading statistics, the perpetuation of harmful stereotypes, and accusations of "tokenism."

\section{OBJECTIVE QUALIFICATIONS}

There are numerous factors that presidents consider when evaluating whom to appoint to the Supreme Court. These include political affiliation, geography, race, health, experience, academic pedigree, religion, and judicial philosophy. ${ }^{3}$ Because of the subjectivity inherent in such a decision, it is difficult to make a compelling case that, in the eyes of a particular presidential administration, any one candidate was objectively more qualified than another. Therefore, it is difficult to substantiate a claim that a candidate was unfairly denied appointment to the Court. Regardless, the authors make such claims throughout the book.

\footnotetext{
${ }^{*}$ Powell Endowed Professor of Business Law, Angelo State University.

${ }^{1}$ Renee Knake Jefferson \& Hannah Brenner Johnson, Shortlisted: Women in the Shadows of the SUPREME COURT (2020).

${ }^{2} I d$. at 17.

${ }^{3}$ For political affiliation, geography, race, and religion, see $i d$. at 40 . For political philosophy, see, e.g., $i d$. at 46 ("Nixon wanted someone who was philosophically compatible with his point of view. And many women in the judiciary were ... not strict constructionists.").
} 
When discussing the first shortlisted woman, Florence Allen, the authors heavily intimate that it was her gender that kept her off the Court. ${ }^{4}$ While Allen certainly "met the basic political, professional, and representational standards for Supreme Court selection,"5 that does not mean it was per se discriminatory that she was not appointed, as many candidates met the basic minimum qualifications. $\underline{6}$ It is certainly possible that a similarly situated man with the same qualifications would have been appointed, and therefore Allen was discriminated against, but there is not enough evidence and far too many unknown variables to be able to substantiate such a claim.

\section{Mistreatment \& Double StANDARdS}

The book provides numerous examples of sexist treatment and double standards that the female shortlisted candidates have faced. Although never explicitly pointed out, it is interesting to note how this treatment evolved over the last 100 years. It is also interesting to note how much of the treatment does not necessarily come from a place of intentional subjugation or vitriol. To the contrary, some of the sexist treatment comes from people who likely had the best of intentions in mind. For example, in a misguided attempt at a compliment, Florence Allen was told that she had a "masculine mind."7 This serves as a much-needed warning that just because someone's intentions are good, that does not mean their actions are beneficial.

Of course, not all of the sexist behavior these pioneering women faced could be considered well-intentioned. A district judge commented that shortlisted candidate Burnita Matthews "would be a good judge [except for] just one thing wrong: she's a woman."8 President Nixon commented, "I don't think a woman should be in any government job whatever. I mean, I really don't. The reason why I do is mainly because

${ }^{4} I d$. at 28. (“Allen's gender surely played a role in keeping her off the Courts . ...").

${ }^{5} I d$. at 25 .

${ }^{6}$ The Constitution does not state any qualifications for justice such as age, education, native-born citizenship, or prior legal experience. FAQs General Information, SUPREMECOURT.GOV,

https://www.supremecourt.gov/about/faq general.aspx\#: :text=Do\%20you\%20have $\% 20$ to $\% 20$ be,been $\% 20$ tr ained\%20in\%20the\%20law (last visited Jan 3, 2021).

${ }^{7} I d$. at 20.

${ }^{8} I d$. at 31 . 
they are erratic. And emotional."9 Shortlisted candidate Mildred Lillie had a law professor who refused to call her anything but "mister."10 These patently sexist attitudes were also well documented in judicial opinions. This is demonstrated in an 1873 Supreme Court concurrence that denied women admittance to the Illinois Bar: "Man is, or should be, woman's protector and defender. The natural and proper timidity and delicacy which belongs to the female sex evidently unfits it for many of the occupations of civil life."11

The authors point out interesting double standards as to how females considered for the Court are described compared to their male counterparts. These examples are simultaneously disheartening in their unfairness and humorous in their absurdity. It is not surprising that female candidates are more likely to be described by their looks. Mildred Lillie was complimented for maintaining "a bathing beauty figure." 12 When shortlisted candidate Susie Sharp made partner, the newspaper explained that the law office is where "she would use her brain, unless she decided to pursue marriage instead, where she would use her beauty." 13 Shortlisted candidate Pamela Rymer was described as "very elegant and always perfectly coiffed ...." 14 The New York Post thought it necessary to describe how shortlisted candidate Soia Mentschikoff wore expensive hats and "expensive undies of sheer, black silk." 15

Other observations regarding candidates for the Supreme Court that are relegated to females include focusing on stereotypical feminine attributes. Media coverage of Ruth Bader Ginsburg included her inability to cook a tuna fish casserole. ${ }^{16}$ And shortlisted candidate Harriet Miers was said to engage in "a lot of girl talk." 17

Susie Sharp provided a clever reply when questioned as to the appropriateness of her presiding over a rape trial. She noted that "since the rape in question could not have been committed without the

${ }^{9} \mathrm{Id}$. at 42 .

${ }^{10} I d$. at 56.

${ }^{11} \mathrm{Id}$. at 2 .

${ }^{12} \mathrm{Id}$. at 1.

${ }^{13} I d$. at 83 .

${ }^{14} \mathrm{Id}$. at 110.

${ }^{15} \mathrm{Id}$. at 150 .

${ }^{16} \mathrm{Id}$. at 117 .

${ }^{17} \mathrm{Id}$. at 120 . 
presence of a woman, it was only fitting that a woman oversee a trial involving this kind of gendered crime." 18

Harriet Miers's experience as American Bar Association president was downplayed even though Justice Powell's experience in this same position was lauded. ${ }^{19}$ President Obama was criticized for touting the "empathy" of Sonia Sotomayor. ${ }^{20}$ But President George H. W. Bush received no such criticism when championing the "great empathy" of Clarence Thomas. ${ }^{21}$

The authors also provide excellent examples of what they refer to as a "double bind." 22 This is defined as "situations in which options are reduced to a very few and all of them expose one to penalty, censure or deprivation." ${ }^{23}$ For example, Florence Allen was given the following, cryptic advice: "[A female judge] must not assume the attitude of a man, either in dress or manner of speech. But she must try her cases in a manly fashion, by which I mean simply be thoroughly prepared and capable." 24

Double standards and sexist remarks are of course not the only hardships documented in the book. Many of the shortlisted women even faced logistical hurdles. For example, Suzie Sharp recounts how she had to walk through the men's restroom to enter the court's chambers..$^{25}$

\section{Perpetuation OF STEReOTYPeS}

Unfortunately, the book comes dangerously close to perpetuating harmful gendered stereotypes. This is due to somewhat of a Catch-22 the authors face. Namely, if the judicial reasoning of a female is indistinguishable from that of a male, then why is it so important to place women on the Court? Conversely, if the presumed gender differences between male and female justices is justification for more women on the court, then these inherent differences surely come up in other areas, where they also warrant gendered consideration. Simply put, advancing the notion that men and women think

${ }^{18} I d$. at 84 .

${ }^{19} I d$. at 120 .

${ }^{20} I d$. at 176.

${ }^{21} I d$.

${ }^{22} I d$. at 151.

${ }^{23}$ Id. at $142-43$.

${ }^{24} \mathrm{Id}$. at 151.

${ }^{25} \mathrm{Id}$. at $83-84$. 
differently is dangerous, as it in turn could perpetuate other gendered stereotypes that cause great harm.

It is certainly true that, on average, women have had different life experiences than men. The authors provide the example of Safford Unified School District v. Redding, ${ }^{26}$ which involved a thirteen-year-old girl who was strip-searched. ${ }^{27}$ It is noted that "none of the men on the bench know what it is like to be a thirteen-year-old girl." 28 While true, this point is of limited value, as the justices frequently decide cases involving situations that they have limited personal experience with. For example, Supreme Court justices also have little to no experience with being on death row, being an undocumented worker, being physically or mentally handicapped, being the victim of police brutality, being a police officer, being the victim of an illegal search, having their speech censored, being homeless, or being an LGBTQ person. Regardless, they routinely render judgments in such cases. Supreme Court justices may analyze social science research, trial court transcripts, and amicus briefs to better understand such experiences.

The notion that personal familiarity with a subject results in superior adjudications in cases involving that subject is never supported with any evidence in the book and is somewhat counterintuitive. Our legal system generally recognizes that a judge's personal familiarity with a subject results in worse, not better, judgements on the matter. $\underline{29}$ That is why, for example, a judge whose black, teenage daughter was killed by a white supremacist would be expected to recuse himself in a case involving a white supremacist who killed a black, teenage girl. .30

\section{QUESTIONABLE STATISTICS}

At times, the authors' use of statistics ranges from misleading to blatantly false. An example of the latter is found in the excerpt "At the end of [Reagan's] two terms, only four of seventy-eight vacancies on federal appellate courts were filled by women, less than one percent." 31

\footnotetext{
26557 U.S. 364 (2009).

27 JEFFERSON \& JOHNSON, supra note 1, at 51.

${ }^{28} I d$.

29 “Any justice, judge, or magistrate judge of the United States shall disqualify himself in any proceeding in which his impartiality might reasonably be questioned." 28 U.S.C. $\S 455$.

$\frac{30 \mathrm{Id} \text {. }}{31 \mathrm{Id} .}$ at

$\overline{{ }^{31} I d}$. at 132 .
} 
The authors point out that "only" $7 \%$ of President George H. W. Bush's judicial appointees were black or Hispanic ${ }^{32}$ and deem this a "lackluster record." 33 This is a deceptive statistic because it ignores how many Republican black and Hispanic lawyers with the requisite experience existed at the time. Considering statistics on black and Hispanic law school graduation rates and voting records provides a rough estimate of how many qualified Republican black and Hispanic people were available for President Bush to appoint. Assuming that blacks and Hispanics made up less than 5\% of lawyers with over ten years of experience at the time, ${ }^{34}$ and assuming that roughly $17 \%$ of black and Hispanic lawyers were Republican, ${ }^{35}$ this results in only $0.85 \%$ of the candidates available for selection by President Bush being either black or Hispanic. With this understanding, the "only" $7 \%$ that he appointed is more than $700 \%$ greater than what would be expected based on a race-neutral selection. It is also interesting to note that President Bush's record of appointing black and Hispanic justices is greater than every president that came before him except only one, President Carter. ${ }^{36}$

President Bush's 7\% figure could serve as an illustrative example of the necessity for affirmative action in law school admissions and discrimination protection at law firms, policies that may lead to more qualified minorities for consideration, but, as demonstrated, it is counterproductive in trying to demonstrate a "lackluster record" in appointing federal judges.

President Bush's predecessor, President Clinton, also receives a peculiar critique in the book. He is chastised for merely "checking the woman box" with his "one token female Supreme Court nominee ...."37 The authors accuse him of being "not willing to actually select more than one woman for the Court." 38 This appears to

\footnotetext{
${ }^{32} I d$. at 112 .

${ }^{33} I d$.

${ }^{34}$ Linda F. Wightman, Law School Admission Council, LSAC National Longitudinal Bar Passage STUDY viii (1998), https://racism.org/images/pdf/LawSchool/Admission/NLBPS.pdf. In the mid-1990s, blacks and Hispanics made up about $6 \%$ of those who passed the bar. Given demographic trends, it is assumed this rate was lower in previous years.

${ }^{35}$ How Groups Voted in 1992, ROPER CTR. FOR PUB. OpINION RES., https://ropercenter.cornell.edu/howgroups-voted-1992 (last visited Oct. 9, 2020) (noting that in 1992 George H. W. Bush received 10\% of the black vote and $25 \%$ of the Hispanic vote).

${ }^{36}$ JEFFERSON \& $\mathrm{JOHNSON}_{2}$ supra note 1 , at 113.

${ }^{37}$ Id. at 117 .

${ }^{38} I d$.
} 
be misguided criticism, as Clinton only made two Supreme Court appointments. ${ }^{39}$

\section{ACCUSATIONS OF TOKENISM}

Likely the most troubling aspect of the book is the numerous accusations of tokenism. The authors claim that "all of the women profiled in this book were tokens in various ways." 40 To clarify, the authors are not just documenting accusations of tokenism that the women had to endure; they are making the claim that, in multiple ways, every woman considered for the Court was a token. ${ }^{41}$ Accusing Ruth Bader Ginsburg as being merely a "token" 42 Supreme Court justice is not only unsupported by the facts but threatens her credibility by implying she was not qualified for the position.

\section{CONCLUSION}

While this review focuses on areas of critique, the book is overall informative and engaging. It provides insight into people and situations that are mostly overlooked and, in doing so, gives the reader a better understanding of the unique challenges females in the legal profession face.

\footnotetext{
${ }^{39}$ Bill Clinton appointed Ruth Bader Ginsburg and Stephen Breyer to the Supreme Court.

${ }^{40} I d$. at 131.

${ }^{41} I d$.

42 "A member of a group (such as a minority) that is included within a larger group through tokenism" Token, MERRIAM-WEBSTER, https://www.merriam-webster.com/dictionary/token (last visited Jan. 5, 2021).
} 